\title{
Saviors who come from the Sea and Earth: The Jinin (眞人) of Korea and Miroku (ミロク) of Japan
}

\author{
Sung-Soon Kim \\ Center for Religious Studies, Seoul National University, Korea \\ shui1@naver.com
}

Publication Information:

Received 23 April 2020, Accepted 1 May 2020, Available online 29 June 2020

DOI: $10.21463 /$ jmic.2020.09.1.06

\section{Abstract}

This article attempts a historical comparative study between the Maitreya faith in early modern Korea and the Mirokukami faith in the Okinawa and Kashimi area of Japan. In Buddhist teachings, Maitreya is a savior figure who will descend to earth 5,670,000,000 years after Buddha Śākyamuni's ascent to nirvana. In the East Asian Buddhist sphere, believers facing what they believed to be the end of the world endowed Maitreya with the image of a political leader and earthly savior. Stone statues of Maitreya stuck in the earth became idols of worship by common people. In contrast, Maitreya of the sea emerged as the image of a political leader who could overthrow the king. In the areas of Okinawa and Kashimi, Maitreya of the ocean appeared in the form of Mirokukami. Mirokukami rode a divine ship and brought Mirokunoyo (meaning good harvest) to the people. In the Ryukyu Islands, Hotei-as an embodiment of Maitreya-fulfilled the role of Mirokukami and combined elements of the ocean paradise Nirai Kanai, indigenous harvest deities, and Maitreya belief. For island villagers, a plentiful rice harvest was equated with salvation, and therefore they held village festivals meant to call up Maitreya's ship from a paradise far out at sea. Ultimately, Maitreya appeared in a variety of forms in Korea and Japan: Buddha buried in the ground, Hotei, Mirokukami, and as the Jinin of the sea. Maitreya was a religious and social symbol which reflected the most pressing needs of the people at the time. Likewise, it can be said it held a striking universality.

\section{Keywords}

Mireuk (Maitreya; 彌勒), Haesangjinin (Ascetic from the Sea; 海上眞人), Jijungmaemolbul (a statue of Buddha half-buried in the Soil; 地中埋沒佛), Haedogibyung (Rebels from the Island; 海島起兵), Mirokukami (Mireuk Deity; 彌勒神), Mirokunoyo (Year of Good Harvest with Maitreya 彌勒世). 


\section{Introduction}

In the Buddhist scriptures, Maitreya ${ }^{1}$ is both the Buddha residing in Tushita Heaven as well as the Bodhisattva promised to achieve complete enlightenment in the future. There are two strains of belief within Maitreya faith. Certain practitioners believe that the Bodhisattva Maitreya ascends to Tushita and follows the path leading to enlightenment in order to save the unenlightened. Other practitioners believe that in 5,670,000,000 years Maitreya will descend to the world of the suffering, attain Buddhahood and redeem the unenlightened. Amongst the various beliefs in Maitreya's return to earth, the deity is often ascribed a messianic role, whereby Maitreya appears as a savior who saves people from apocalyptic dread and delivers them to a new world.

In the East Asian Mahayana Buddhist tradition of Buddha and Bodhisattva faith, there are multiple examples where the meaning of Buddhist doctrine and the appearance and practice of faith in the real world diverge. A typical example of this is Maitreya faith. Maitreya removed from the teaching and scholarship of the Buddhist scriptures has been interpreted in various ways and has transformed in appearance, as it was adapted to different human needs and desires. In China, Maitreya became the figurehead for a society of religious rebellion. In the late Joseon dynasty, he emerged a symbol for challenging the king among groups of Maitreya believers. Maitreya faith also transformed into the figure of the $\mathrm{Jinin}^{2}$ of the sea, while in the island regions of Japan, Maitreya was worshiped as a harvest god who alleviated hunger.

This article compares the cases of Korea and Japan to demonstrate how common people actively interpreted and utilized Maitreya belief to solve real life problems. My primary target of analysis is Maitreya stone statues scattered around the mountains of Korea and Maitreya's transformation into a Jinin of the sea. I also examine instances of Mirokukami ${ }^{3}$ on the Japanese archipelago, and consider the historical context of Maitreya religious faith in both Korea and Japan. Considerable research has been conducted on Maitreya religious belief in Korea and Japan, respectively. As for comparative studies, the work of Hiroko Tabata stands out. ${ }^{4}$

Common to all religious phenomena, Maitreya faith undergoes continual transformation according to changing circumstances of time and place. An analysis of all these detailed phenomena would only be appropriate for a longer work, which would require an extensive investment of time and the exhaustive collection of primary materials. This contribution limits its scope to particular places in Korea and Japan during the early modern period and compares varied instantiations of Maitreya belief. In the process, I attempt to reveal a universality of religious faith that exceeds differences occurring across cultures of Maitreya belief.

\section{Maitreya of the Earth — The Buddha Buried in the Ground}

The vow of Bodhisattva Maitreya is to observe the Buddhist precepts and strive for enlightenment while avoiding the violence that accompanies the degeneration of human society, the overthrowing of the current order, and finally revolutionary change. According to the Buddhist texts, Maitreya does not descend to earth during times of destruction 
and demise. Rather, Maitreya will return to deliver the Buddhist teachings of salvation once humans have made a world pure and free from evil in accordance with the religious precepts of Buddhism.

In regards to Maitreya's return to earth, accounts differ among different Buddhist texts. However, accounts generally converge on the time of 5,670,000,000 years in the future and the space of the Bodhi tree. Believers in Maitreya's descent to earth trust that Maitreya will hold three assemblies under the Bodhi tree whereby the people will be saved through Maitreya's expounding of the dharma. ${ }^{5}$

In Buddhist scriptures, Maitreya's descent to earth occurs after 5,670,000,000 years. However, when reviewing religious history, periods of popular belief in Maitreya as a messiah who will save the world are often accompanied by political upheaval and rampant religious corruption. Moreover, there is an endless occurrence of religious rebellions where religious leaders claiming to be Maitreya promise to establish a religious kingdom reminiscent of Maitreya's earthly heaven. In Korea, the short rule of King Gungye is a paradigmatic example. ${ }^{6}$

Periods when Maitreya faith was prevalent tended to be times of social confusion and transition. For example, the turbulent times at the end of the Silla period; the military peasant rebellions of the late Goryeo period; the period of Mongol invasion; the forty or so years of intrusions by Japanese raiders at the end of the Goryeo period; and late Joseon society after the second Manchu invasion of Korea in 1636 are all periods where Maitreya faith was popular. In addition to the Yeohwan led uprising under King Sukjong, there is also a record of a woman called Maitreya Saint by her followers. They performed worshiping ceremonies and believed they would ascend together to the world of Maitreya (Ilseongnok. January 18, 1786). Is it not likely that followers of Mahayana Buddhism-who desperately craved the return of Maitreya to save them from the hopelessness of the current world-would have looked to other Buddhist texts for answers?

When the Buddha said this all the lands of the great manifold cosmos in the sahā world quaked and the earth split. From out of this crevice there simultaneously appeared incalculable thousands of myriads of kotis of bodhisattva mahāsattvas. All of these bodhisattvas had golden bodies endowed with the thirty-two marks and radiating immeasurable rays of light. They had all previously been living in the space under the earth of the sahā world. Having heard the sound of Śäkyamuni's teaching, all of these bodhisattvas emerged from below. (The Lotus Sutra, SAT No.262 Vol.9.0039c29-a04)

The above passage from "Bodhisattvas Emerging from the Earth" in The Lotus Sutra teaches that an innumerable number of Bodhisattva Mahāsattvas, who had been living in an empty space under the world, heard the teachings of Sākyamuni and poured forth from a split in the ground. In this passage, Maitreya receives the prophecy of attaining Buddhahood from Śākyamuni in front of numberless Bodhisattvas and their retinue who have spouted from the earth. The following except is from the same chapter and illustrates another important scene relevant to the view of time in Buddhism.

All these bodhisattva mahāsattvas, having emerged from the earth, praised the buddhas with various bodhisattva eulogies. While they did so, fifty intermediate kalpas passed. During this time the Buddha Sākyamuni sat in silence; and the fourfold assemblies were also silent while the fifty intermediate kalpas passed. Because of the Buddha's transcendent powers, the great assemblies believed that the time that had passed was only half a day. (The Lotus Sutra, SAT No.262 Vol.9.0039a19-a21)

The above passages describes a scene where the limits of physical time are transcended in the sacred space where Śākyamuni's teachings are being preached. Due to the Buddha's transcendent powers, the great assemblies felt that the passing of 50 kalpas $^{7}$ had taken only half a day. In the Mahayana scriptures, transcendence of spatial and temporal limits through the magnificence of the Buddha and the Bodhisattvas and the power of their teaching appear often. In this 
sense, in spaces where Buddha and Bodhisattvas appear, the unimaginably long time of 5,670,000,000 years can be condensed into shortened temporalities immediate for believers.

Therefore, the time of 5,670,000,000 years that begins after Buddha Saakyamuni's entering nirvana is replaced by an insistence on the here and now. As a result, Maitreya faith becomes a belief that paradise will be constructed on earth. (Jang Jihun, 1997) Moreover, the very place (here/now) at which the Buddha and Bodhisattvas "emerge from the earth" allows for the realization and transformation of a pure land without bondage on earth. I believe that for leaders of uprisings and a public who longed for change, the image of the Maitreya Buddha emerging from the earth would have been the most attractive and convincing element of the Buddhist scriptures. Let's attempt to transplant these two scenes -Buddha and Bodhisattvas' emergence form the earth and the passing of 50 kalpas in half a day-to the land of Korean Maitreya belief. According to records of the stone statue of Maitreya at Gwanchok Temple, a large boulder emerging from the earth symbolizes Maitreya's appearance (Gwanchoksa sajeokbi).

Moreover, such symbolism is based on the belief in Maitreya's earthly return passed down since the Baekje period (18 BC - 660 AD). The Korean scholar Choe Jongrye gives the name "Buddha emerging from the earth" to Maitreya idols, which "give the effect of surging out of the ground." (Choe Jongrye, 2006) The Buddha emerging from the earth is often a statue of Buddha with the knees or waist submerged in the ground. Therefore, in the case of a stone Buddha statue whose upper body is comparatively larger to that of its lower body, it is assumed the statue was originally designed and carved to be placed in the ground. Korean scholar Ju Ganghyeon has called such Maitreya statues "Buddha with lower body buried." (Ju Ganghyeon, 1995).

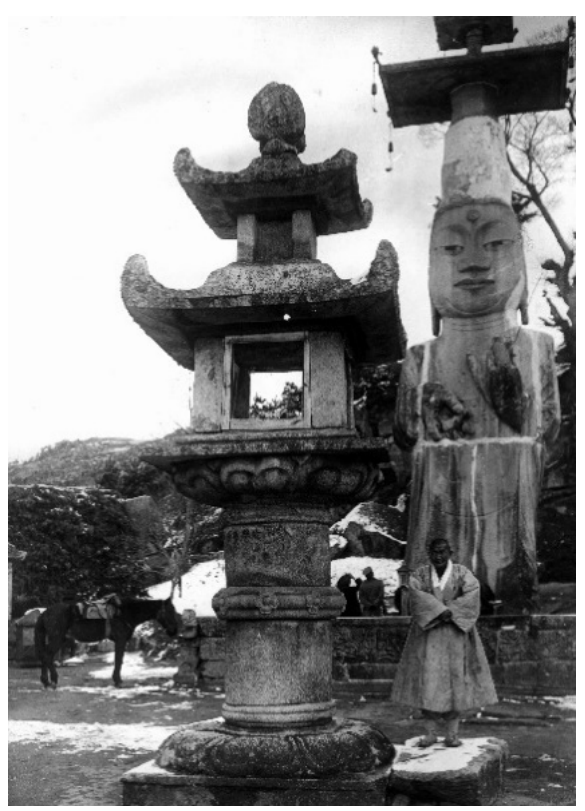

Fig 1. Chungnam Nonsan Gwanchoksa MireukSukbul (photo from National Museum of Korea)

In Korea, many half-buried Maitreya statues still exist. For example, the Mipyeong Village statue of the healing Buddha in Yongin, Gyeonggi Province; the Sinan Village standing stone Buddha statue in Yeongdong County, Chungcheong Province; the Kusu Hamlet grandmother Maitreya statue in Guam village, Mujang Township, Gochang County, North 
Jeolla Province; the standing Buddha statue of Okdae Village in Youngju, North Gyeongsang Province; the Maitreya statue in Nambok Village, Gobu Township, Jeongeup City, North Jeolla Province; the stone standing Maitreya statue of Gwanchoksa Temple; the Maitreya statue in Gueup Village, Gunnae Township, Pocheon City, Gyeonggi Province; the Maitreya statue in T'osa Village, Tongjin Town, Gimpo City; and the boulder Maitreya in Gayang Village, Hongsan Township, Buyeo County, South Chungcheong Province. In addition to these statues, there are likely other instances of stones naturally sticking out of the ground having been worshiped as idols of Maitreya.

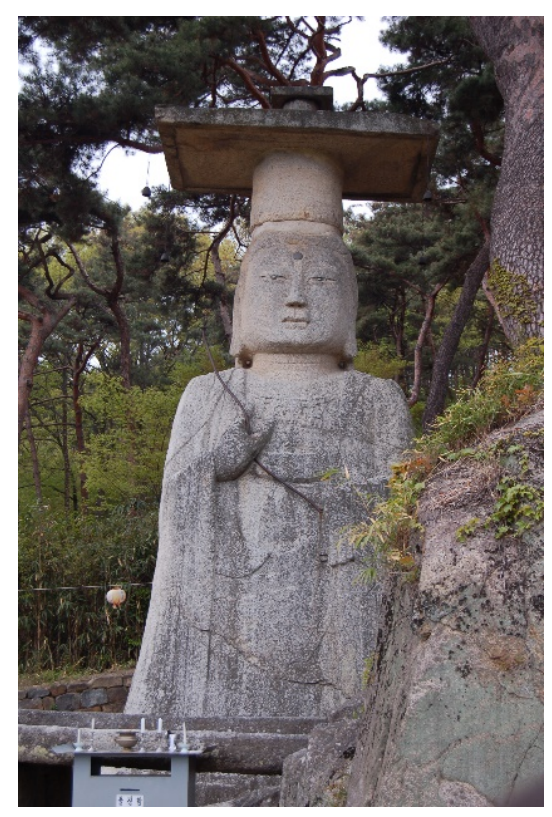

Fig 2. Chungnam Buyeo Daejosa Mireuksukbul (photo from Northeast Asian Buddhist Art Research Institute)

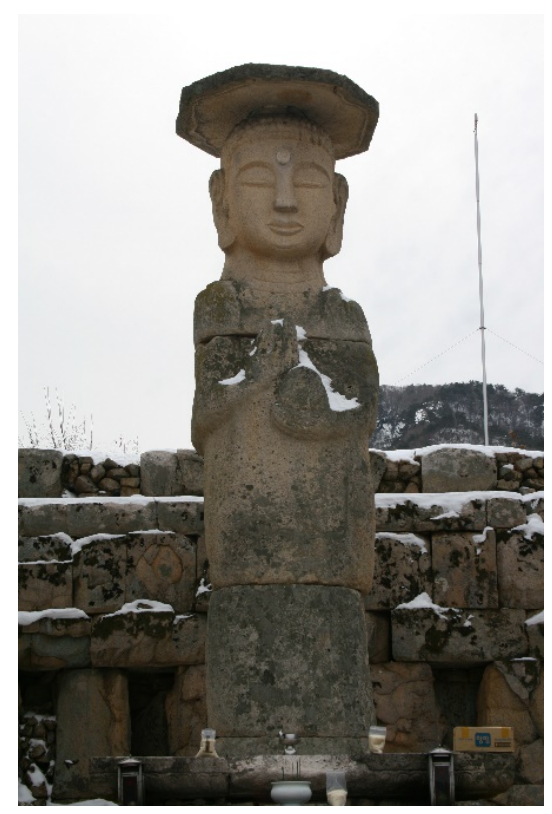

Fig 3. Chungju Mireukdaewon Mireuksukbul (photo from Northeast Asian Buddhist Art Research Institute) 
Entering the Joseon Dynasty, Buddhism was maintained by ordinary people, and the strain of Maitreya faith never disappeared from the foundations of popularized Buddhism. In addition to the Japanese invasion of Joseon in 1592 and the Manchu invasion of Joseon in 1636, common people suffered structural inequalities due to the caste system and military service system. Indeed, common people would have felt they were living in an era of great decline. As a result, Maitreya religious faith in the Joseon period is defined by a strong belief that Maitreya, as the future Buddha, would descend to earth to deliver people from the pain and suffering of the present.

Ultimately, Maitreya who springs from the earth is a projection of the people's spiritual desire for the establishment of the wondrous world of Maitreya on earth. Leaders of Maitreya-inspired rebellions understood this zeitgeist and manipulated the teachings of Maitreya and Jinin to make them accessible to the people.

\section{Maitreya of the Ocean — The People Waiting for the Jinin of the Sea}

It is without a doubt that physical and mental injuries inflicted on the people by the Japanese Invasions of Joseon (1592 and 1598) were extensive. These events also had a measurable effect on politics, culture, and society. Although JapanKorean diplomatic relations recommenced in 1607, issues of cultural superiority and trauma related to war persisted, meaning complete resolution was impossible. (Hong Seongdeok, 2017) The multi-layered feelings of Koreans towards Japanese are complexly reflected in such prophetic texts as Jeonggamnok.

In the fourth year of King Yeongjo's rule (1728), leaders of various ostracized political factions led large-scale military uprisings in Chungcheong Province, Jeolla Province and Gyeongsang Province. Some of these leaders fled to islands such as Ulleung-do Island and were continually associated with prophecies of the "prophecy of a Jinin from the island on the sea." This prophecy became popular in the late 17th century, and was one type of prophecy, which stated that a Jinin would emerge from an island in the sea and bring about a new world. Jinin, the ultimate ascetic sought by Taoism, is recognized by the people as a transcendent political leader and military leader. This was also a belief that reflected the people's wish to save the world in distress with the powerful and transcendent power that the Jinin gained through ascetic practice. Such a tale was unique for its time, as it postulated a savior figure that was a practitioner at the highest level of Taoism who would cross the ocean onto land. Such tales of a Jinin from an island on the sea continually appear in relation to uprisings based on a variety of prophecies and writings of divination in the late Joseon period. ${ }^{8}$

In records documenting the Yi Jiseo rebellion in the 24th year of King Yeongjo (1748), there is mention of rebellious factions who gather on islands.

Yi Jiseo talking, 'Although the weather these days is fair, what is the reason for not raising a signal fire? By the people's account, there is much panic and chaos, with some saying that the Japanese are coming. When in truth, those coming are not Japanese but made up to look like Japanese people. They are remnants of the rebellion who have gone to an island at sea.' (Yeongjo sillok. May 23, 1748. Vol. 67.)

In this excerpt, the phrase "not Japanese but made up to look like Japanese" appears. This confession reveals an irresolvable contradiction on the part of the speaker: it displays a psychological desire to imitate the strength of Japanese invaders who threatened the Joseon dynasty, while still acknowledging that to identify with the Japanese is impossible. Put differently, this passage embodies the concerns of rebellious forces. Although they want to imitate 
Japanese strength-which forced King Seonjo's retreat to Uiju and the emptying of the royal palace-they know better than to identify with Japanese invaders.

Moreover, the mentioning of Ulleung-do Island and Japanese people in reference to the rebellion is intimately related to the tale of the "Jinin who raises an army on the island at sea" from the prophetic Korean text Jeonggamnok. After the 18th century, Ulleung-do and other islands were considered social problems because they were places of assembly and exile for drifting migrants, thieves, escaped slaves and those plotting to commit treason. Islands that were beyond the control of the Joseon government were implicated with the symbolism of Japanese invaders and were associated with treason and revolt (Hong Seongdeok, 2017).

The "Jinin who raises an army on the island at sea" prophecy can be seen as an extension of both the "Jinin from the island on the sea" prophecy and the "Jinin from the south" prophecy. The savior who would emerge in the "Jinin who raises an army on the Island at Sea" tale is both a military leader and the one who will save the people from their painful existence. In short, the tale is heavily messianic in nature (Gim Ucheol, 2012). Up until the end of the 17th century, saviors generally appeared either in other worlds or on land. However, beginning in the 18th century, islands take on this function. This change is predicated on the movement of common people to islands and the government's lack of control over these areas in the 17th and 18th centuries. (Bak Sanghyeon, 2015) Migrants who moved to islands either minted money, traded with vessels of uncertain nationality, and even seized tax vessels. In the Honam region, migrants flocked to islands and even formed loose affiliations. At Byeon Mountain in Buan County, pirates held their territory while plundering in broad daylight and even chased Buddhist monks out of a large temple and occupied the temple as their base of operations (Yeongjo sillok. October, 1727. Vol. 14.).

In the uprisings of the 17th and 18th centuries, the concepts of "Jinin of the sea" and "the Jeong family line" overlap. The Jeong Jinin who came from an island far in the south made the sea black with the warships he brought and came to bring forth a new world. The people can also interpret this as the projection of a magnificent power onto the Jinin of the sea - a power needed to overthrow the king, who was seen by the people as weak for fleeing and surrendering when attacked by outside forces.

In the 11th year of King Jeongjo (1787), Gim Dongik and other Buddhist monks were beheaded for treason. In the record of this incident, mentions of islands appear. The belief which spurred the uprising was a prophecy of a Jinin from an island that would bring enough ships to turn the sea black, seize the thrown, and save the people while bringing about a new age.

Gim Dongik and fellow traitors were executed. ... It was said, "Gim Jeungyeol had gone out with a Buddhist monk. For many years the monk had been making trips to the land of bliss of Amitabha Buddha in the west, but he had been hiding this fact and told no one. Now I have heard that they raised an army on an island in the ocean and in reverence for Jeong Huiryang's grandson Jeong Ham, they planned to follow through with everything on the 11th and everyone across the country responded to the call."... "Before Gim Jeungyeol left, he met a wise Buddhist monk in Chungju, and the monk insisted they travel together out onto the ocean. Gim Jeungyeol did not follow at first, but after the coming of the bitter cold of the southeast wind, he regarded it as the word of the wise monk and fled with the monk." (Yeongjo sillok. June 14, 1735. Vol. 23.)

The above record of Gim Jeungyeol following a wise Buddhist monk to an island in the ocean indicates that in 18th century Joseon society belief in the prophecies contained with the book Jeonggamnok was prevalent. At the end of the 17th century, prophecies of the appearance of the living Buddha and of a Jinin began to combine with the prophecies of the fall of the Yi family and the rise of the Jeong family. The union of the living Buddha prophecy and the appearance of 
the Jinin prophecies is visible in the 1691 living Buddha incident brought about by shamans. In this incident, a living Buddha appears as a symbol of healing and fortune who will receive the future nation. Maitreya's earthly incarnation as a living Buddha displays Maitreya's transformation in the minds of the people into the one who will replace the Joseon Dynasty. ${ }^{9}$

The Jinin with the family name Jeong was received as both an idol of the people and as a liberator who will bring about an egalitarian society free of pain and suffering. The people believed that the Jeong Jinin would at any moment arrive from an island across some ocean to free them from feudal oppression. (Ju Ganghyeon, 2012) The Jinin who would raise an army on an island, penetrate deep into the heart of Joseon and overturn the dynasty to establish an egalitarian society was also the Maitreya Buddha who would establish a wondrous paradise of Maitreya on earth. Both leaders of rebellions and common people projected their expectations of an imminent savior Buddha in the form of Maitreya onto the Jinin of the island in the ocean who wielded real military power. In the end, the marriage of the "military force" of Jinin of the sea with the "saving force" of Maitreya in the imaginations of the people attests to the inseparability of Maitreya belief and societies of rebellion in the late Joseon period.

\section{Japan's Maitreya of the Sea - Mirokunoyo and Mirokukami}

After passing through China and Korea, Maitreya belief penetrated Japan where it was combined with traditional spirituality and became rooted in common people's beliefs. (Miyata, Noboru, 1968) By the Nara period in Japan, temples worshiping Maitreya Buddha as the principle icon began to appear, and near the end of the Heian period the doctrine of Maitreya paradise had spread widely. It wasn't until the Muromachi period that Hotei - one of the seven gods of fortune who bring luck and wealth - began to be thought of as an embodiment of Bodhisattva Maitreya (Sudo, Yoshihito, 2003). Regardless of the identity of Maitreya as Buddha and Bodhisattva within Buddhist teaching and scholarship, among common people in Japan Mahayana Buddha and Bodhisattva deities became integrated with local gods and beliefs. This article discusses "Maitreya who came from the ocean," and is primarily concerned with belief in the deity Mirokukami ${ }^{10}$ in Okinawa and the surrounding archipelago, as well as the islands of the Kanto region.

Kashima in the Kanto region is the most paradigmatic example of Miroku belief. Kashima is located in the eastern most part of what used to be Yamato Province, facing the ocean to the east. In the Kashima region, a good harvest is expressed as "Mirokuyugahu" and the year of a good harvest is called "Mirokunoyo." Villagers represent gods playing and dancing at an annual festival, and this activity is called "Mirokuohdori." Originally, Mirokunoyo referred to an eventual world where Maitreya would descend and save the people, but villagers use the same word to refer to a year of good harvest. Even if merely a simple concept of utopia, Mirokunoyo served as a definite doctrine of salvation according to which villagers would be saved from the hunger and pain in the earthy realm.

The majority of inhabitants of Kashima were farmers and fishermen and they placed their hopes for a god to come across the ocean and deliver a good harvest and plentiful fishing in the Mirokuohdori ritual. Additionally, Miroku's importance as a harvest deity mixed with the indigenous beliefs of Kashima. (Miyata, Noboru, 1975) To reiterate, Mirokukami is the concept of the Buddhist deity Maitreya as it was fused with the local fishing and farming deities of the Kashima region. 
Next, if you examine the various forms of the Mirokuohdori ritual dispersed throughout the Okinawa region and Yaeyama Islands, ${ }^{11}$ one can observe that Miroku has the characteristics of a Japanese joy-bringing spirit. (Miyata, Noboru, 1975) This claim is reflected in the belief that, "Once a year the Miruku spirit collects grain seeds from the ocean in the East, then rides a divine ship filled with Mirokunoyo and comes to bring a good harvest." Moreover, depending on the place, Miroku is also called "Miruku." This is presumed to be a change resulting from the linguistic particularities of the Ryukyu Islands. (Miyata, Noboru, 1975)

Conventionally, the Miroku of the Yaeyama Islands appears in parades to pray for good harvests held in a town square or at the plaza of a citizen-meeting hall in the middle of June. A big Miroku mask is worn, there is a large inflated ship, and people wear yellow clothes and carry a Japanese war fan in the right hand and a cane and a gourd dipper in the left hand while wearing wooden shoes. (Miyata, Noboru, 1975) The people of Yaeyama Islands express the ripening and plentiful harvest of the rice plant and the image of Maitreya bringing the Mirokunoyo harvest through a fantastic costumed parade.

Traditionally, villagers would gather, sing a variety of songs and dance loudly at this harvest ceremony in order to welcome the spirit who brought a good harvest from across the ocean in the East. Among the many folk songs, lyrics often emphasized the anticipation of the coming of "Mirokunoyo" brought by the spirit Miroku.

Of the 21 songs of "Mirokuota" of the Yaeyama Islands, Maitreya is the only spirit who becomes the object of worship for good harvest (Tabata, Hiroko, 2003). The following excerpt is an excellent example of lyrics about Maitreya.

Bring the world of good harvest, our Buddha's miraculous ship

Where, where will the ship land? our Buddha's miraculous ship

Did the ship dock in front of the village? our Buddha's miraculous ship

If it's full of millet or full of rice, no matter it will be plentiful (Tabata, Hiroko, 2003)

Looking at the above excerpt, also contained in Maitreya's ship is Mirokunoyo, a world of good harvest. Therefore, it is observable that villagers believe that on the land where Maitreya's boat docks they will reap a plentiful harvest.

Maitreya's visit was not the actual bringing of rice and grain, but rather a guarantee and a promise of plenitude, showing that in this regard Maitreya belief contained an aspect of the 'cargo cult'12 phenomenon. Additionally, at various festivals on the Yaeyama Islands, the Miroku deity was worshiped as a woman, who would travel with children and partake in parades with a basket full of rice plants. As can be seen, this Maitreya is a completely different interpretation from that of the Buddhist Maitreya. Villagers of the Yaeyama Islands projected a savior image of Maitreya onto their indigenous concepts of fertility and harvest gods. Therefore, how exactly did Maitreya of Tushita Heaven come to be a harvest god who brought a plentiful rice harvest?

The identification of a world of plentiful rice farming with "Mirokunoyo" expanded alongside the spread of rice farming. (Miyata, Noboru, 1971) It is claimed that the belief that "Mirokunoyo" equaled a world of plentiful rice farming emerged in the interactions and negotiations between Okinawa and South China. Those in Okinawa as a land of fertile farmland envied the Annam region, known as a rice-producing district. (Miyata, Noboru, 1971) Therefore, the meanings behind village festivals in Okinawa reflected a belief that Maitreya would come from the plentiful lands across the ocean from the direction of Annam - most likely fueling villagers' imaginations about a deity who would arrive from a far off island.

The costumed festival associated with Mirokukami on the Ryukyu Islands involved a ship blown up like a balloon, the exposing of the belly button, and a smiling, double chin face resembling a full moon-precisely the image of the deity 
Hotei. The process by which Hotei became accepted as a being that would bring plenitude is still uncertain, but Miroku faith in Okinawa and the Yaeyama Islands bears a strong resemblance to similar types of worship in rice farming areas of East Asia where deities appear at harvest ceremonies to guarantee a plentiful harvest. (Miyata, Noboru, 1971) An influential theory holds that Miroku faith on the Ryukyu Islands did not arrive from the Japanese mainland but was likely the result of influence by South China which understood Hotei to be an embodiment of Bodhisattva Maitreya (Sudo, Yoshihito, 2003). In this view, Hotei Maitreya faith expanded from South China to the Annam province in Indochina before finally spreading to the Ryukyu Islands.

Additionally, in the Ryukyu Islands there was a concept of a utopian ocean paradise called "Niraikanai" in the ocean to the east where deities were said to live. It was believed that the deities living there would visit island hamlets and bring plentiful grain. (Sudo, Yoshihito, 2003) There is an opinion that Ryukyu Islands people combined the Buddhist Maitreya faith with the indigenous Niraikanai faith, which resulted in the belief in "the joy-bringing spirit Miruku who brings a plentiful harvest." (Sakihara, Kōshin, 1979) At the same time, when considering the Buddhist Maitreya faith and the concept of paradise in Tushita, its mutual fusion with Niraikanai belief is not difficult to imagine.

Ultimately, faith in an ocean paradise, Maitreya faith, and Hotei as an embodiment of Maitreya were represented in Kashima, Okinawa, and the Ryukyu Islands through harvest deities and Niraikanai. These deities were transmitted over the ocean, and Maitreya residing Tushita was reinterpreted as the deity who, in the image of Hotei, would bring Mirokunoyo to the people.

\section{Savior from the Sea: Miroku and Jinin}

In the late Joseon period, the medieval order collapsed and in the resulting social chaos, the people's desperate demands for a revolutionary utopia spread. Two examples are the mythical nation of Yultoguk in the tale of Hong Gildong authored by Heo Gyun, and the deserted island in the story Heosaengjeon by Bak Jiwon. (Hwang Seonmyeong, 1999)

As stated earlier, in late 17th century Joseon, the purely mythical prophecies of the "Jinin from the sea" and "Jinin who raises an army on the island at sea" played an important role in supporting uprisings and conspiracies against the king. The Jeong Jinin from the sea took on the symbolism of Maitreya, and became the unseen leader of a rebellion in response to the desires of the people for a new world.

In Japan, after the Onin War (1467-77) of the Morumachi period, society was thrown into confusion and poverty. At this moment, Maitreya belief quickly gained popularity. Around this time, it appears that in certain documents the phrase "2nd year of Maitreya" was adopted as an era name. (Yanagita, Kunio, Kaijō no michi, 2005) This can be seen as a reflection of the mentality of the people, who when facing an era of great decline, were desperate for the appearance of Maitreya to deliver a new world.

In Joseon society, people's uprisings occurred while waiting for the arrival of the Jinin of the sea. Likewise, in the early modern period of Japanese society, ${ }^{13}$ struggles to bring about a new world coalesced in the Yonaoshi movement. Yonaoshi was directly relevant to the lives of people of that time, as Yonaoshi brought continual affluence and good harvest to island people who could never sufficiently fill their boats with grain. In precisely this context, Mirokunoyo, 
meaning a good harvest, is linked with Yonaoshi. Villagers did not simply wait for the harvest to come, but rather called Mirokukami to the village. The people's Yonaoshi beliefs accompanied theories about the end of the world. Seeing things that threatened their lives such as earthquakes, volcanic eruptions, tsunamis, floods and other radical changes in the environment, villagers believed that the Yonaoshi they longed for would allow for a life without hunger and natural disaster.

Just as in Korea, Japanese people's awareness of living in an era of great decline influenced their understanding of the Maitreya prophecy and prohibited believers from waiting the promised 5,670,000,000 years before Maitreya's return. In order to receive salvation in the here and now, believers summoned Maitreya from the future. ${ }^{14}$ Both Miroku in Okinawa and the Jinin of the sea from Joseon were beings that could solve societal injustices resulting from political instability and alleviate hunger resulting from environmental disruptions. As such, they were similar messianic figures. However, a concrete analysis of each deity reveals that they also differed in many ways.

First, the Miroku called forth to bestow a good harvest by the people of Okinawa and Yaeyama Islands can actually said to be not Maitreya Buddha but rather a joy-bringing spirit wearing the mask of Miroku. If we look at Miroku belief in Kashima and the Okinawa area, it contains both aspects of indigenous harvest gods while also having the appearance of Hotei-a result of interaction and influence with China and East Asia.

In comparison, the Jinin of the sea who appears in the Korean prophetic book Jeonggamnok can be said to be a military rebel leader who contains aspects both of a practitioner of Buddha-dharma who has reached the highest stage of Taoism, as well as a Bodhisattva Maitreya. Maitreya's revolutionary symbolism, embodied in Maitreya's savior status as the one who will establish a new beautiful world, is projected onto the Jeong Jinin who will raise an army on an island far out at sea. ${ }^{15}$

In Korea, Maitreya morphs into not just a Jinin of the sea, but also appears as a stone statue worshiped by villagers, as well as a Buddha half buried in the ground. Comparatively, in Japan, Hotei - one of the seven gods of fortune becomes accepted as an embodiment of Maitreya, an obvious difference to Korea. Only recently in Korea can you find stone statues of Hotei in temples. Traditionally, examples of Hotei worship are almost nonexistent in Korea. This shows that Hotei worship from Chinese Buddhism did not have an opportunity to take root in Korea due to the existence of stone Maitreya statues scattered all throughout Korea.

\section{Conclusion}

Maitreya as summoned in the Buddhist scriptures is the future savior who will rescue the unenlightened masses through the teachings delivered at the three assemblies under the Bodhi tree after Maitreya descends to earth 5,670,000,000 years following Śākyamuni's entrance into nirvana. Maitreya belief merges with belief in the decline of humankind and an eschatological view of history. Consequently, Maitreya - who in the Buddhist doctrine in no way resembles a military leader - emerges as a symbol of revolt, and leaders of rebellions project the image of Maitreya onto themselves.

The leaders of people's uprisings in the late Joseon period advocated Maitreya belief, while also summoning the "Jinin of the sea" from the prophetic book Jeonggamnok-who resembled Maitreya in character. Prophecies of a "Jinin from the 
sea" or "Jinin from the southern sea" coming from a distant island with an army and innumerable number of ships to bring about a new world served as a catalyst for people's uprisings. In contrast to the stone Maitreya statues sticking out of the earth, which became objects of worldly worship, Jinin of the sea were endowed with the characteristics of strong military leaders who would right the wrongs of the present age.

In Kashima in the Kanto region and the Okinawa area, belief in Miroku was expressed in ceremonies such as Mirokuohdori. Moreover, judging from the fact that it was believed Mirokukami rides a divine ship to bring Mirokunoyo, meaning a good harvest, to villagers-it can be surmised that Miroku is another instance of Maitreya belief that places Maitreya in the ocean.

In Okinawa and the Ryukyu Islands, Mirokukami was believed to be a deity who would bring a good harvest from Nirai Kanai, a paradise on the far side of the ocean. In particular, such beliefs were extremely prevalent in the Yaeyama Islands. Mirokukami was a combination of the deity Hotei, an embodiment of Maitreya, and harvest deities indigenous to the Ryukyu Islands. Therefore, Mirokukami can be seen as a reflection of the people's desire for a world without hunger and starvation.

Just as Hotei, one of the seven gods of fortune was worshiped as a god who could satisfy the earthly needs of Japanese people, Mirokukami in Okinawa and Kashima had the characteristics of a harvest god who came from far across the ocean to bring eternal good harvests.

In both Korea and Japan, Maitreya appears in a variety of forms: Buddha buried in the ground, Hotei, Mirokukami, and as the Jinin of the sea. Maitreya was a religious and social symbol, which reflected the most pressing needs of the people at the time. Likewise, it can be said it held a striking universality.

\section{Endnotes}

1. Maitreya ('Mireuk' in Korean) is a Buddhist Bodhisattva in charge of saving the future world. Mireuk has always been the subject of popular faith in East Asia in the context of political revolutions, as it emerges with Chakravartin, the ideal political leader.

2. 眞人; an ascetic who has reached the ultimate stage of Taoist asceticism.

3. 彌勒神; Originally, Maitreya is the Buddhist Bodhisattva, and is the Buddha of the future, but in this area, it's worshipped as a divine being.

4. Tabata, Hiroko, "Miroku shinkō: Okinawa to kankoku no miroku setsuwa no hikaku kenkyū," Okinawa bunks kenkyū 29 (2003). This article introduces the existing literature on Mirokukami in Japan and analyses the lyrical content of the two folk songs "Mirokuyō" and "Mirokuka."

5. The core of the Maitreya belief is that Maitreya Bodhisattva, who is currently ascetic training on the celestial Dosolcheon (Tushita heaven), will come down to the this world after 5.67 billion years and save all the creatures by doing three sermons under a Bodhi-tree named Yonghwasoo (龍華樹).

6. Gungye (弓裔, ? 918) was a political and military leader who founded the country called Taebong in the post-Three Kingdoms Period. $\mathrm{He}$ is believed to have advocated a persuasive Maitreya religion to the public because he had been a Buddhist monk in his childhood. 
Another example of this is the "Mahayana Bandits (大乘賊)" rebellion of 515 and Wu Zetian's usurpation of the throne. Both rebellions show that these Maitreya believers did not expect the arrival of Maitreya in the far distant future, but instead substitute this doctrine for a belief of Maitreya's imminent return to earth. In Chinese Buddhism, the religious uprising concerning this belief in Maitreya is called “Robbing of Maitreya Teachings (彌勒敎匪).”

7. 劫; the period from the birth of a world to the end.

8. According to historical understandings, the "prophecy of a Jinin from the island at sea" describes a Jinin who lives on an island. The "prophecy of a Jinin who raises an army on the island at sea" describes the gathering of an army on an island. The "Jinin form the south prophecy" similarly relates to a Jinin living on an island in the southern sea. The armies led by Jinin were believed to be the descendants of the Ming dynasty, which had been destroyed, by the Qing Dynasty, as well as the remaining powers of uprisings such as the Mushin rebellion. (Han Seunghun, 2014).

9. However, because mainly shamans and monks propagated the prophecy of the living Buddha, it was not developed into a more systematic doctrine for continuous resistance. This is because the Chŏng living Buddha they advocated was limited by its reliance on religious ceremonies such as "Sky Ceremony between the Mountains." See (Pak Sang-hyŏn, 2015).

10. Mirokukami is the Japanese term for Maitreya.

11. The Yaeyama Islands are part of Okinawa Prefecture. These islands are the farthest islands from the mainland of Japan and include both Hateruma Island, Japan's southernmost inhabited island, and Yonaguni Island, Japan's westernmost inhabited island. The Yaeyama Islands are closer to Taiwan than Okinawa.

12. Cargo cult refers to the belief system that in a primitive society, a savior who carries rare objects across the sea from faraway lands will arrive. The corresponding case in the text expresses the belief in the Mirokukami, which is loaded with rice, to the coastal areas of Japan.

13. Generally, the early modern period in Japan is considered the time of the Edo Bakufu feudal government lasting from 1603 to 1867.

14. In the Book of Maitreya's Return the time of Maitreya's descent to earth (『Bulseolmireukhasaengyong (佛說彌勒下生經)』) is linked to the era of great decline, and therefore established the belief that even in the here and now Maitreya can return to earth to save the unenlightened masses and establish a blissful paradise. (Gim Myeonghui, 2011).

15. According to the Book of Buddhist Teachings on Maitreya's Return, at Maitreya's first Dharma assembly after returning to earth, 96 million of the unenlightened will attain nirvana, at the second assembly 94 million, and at the third assembly, 92 million will attain nirvana.

\section{References}

Bulseolmireukhasaengyong (『佛說彌勒下生經』) (Classic Chinese)

Joseonwangjosilok (『朝鮮王朝實錄』) (Classic Chinese)

Gwanchoksa sajeokbi「(灌燭寺事跡碑)」(Classic Chinese)

Ilseonglok (『日省錄』) (Classic Chinese) 


\section{Myobeopyeonhwagyong (『妙法蓮華經』)(Classic Chinese)}

Bak, Sanghyeon, 2015, “'Haedo jinin seol' ui byeonhwa yangsang gwa uimi.” Yeoksa wa hyeonsil 96, p.225. (Korean)

Choe, Jongrye, 2006, Mireuk ui nara; (Land of Mireuk). Seoul: Uri, p.325. (Korean)

Gim, Myeonghui, 2011, “Jeungsando ui mireung mireuk sinang suyong gwa jeongae gwajeong." Hangung Hanguk bulgyohak 61, p.81. (Korean)

Gim, Ucheol, 2012, “Joseon hugi byeollan eseoui jeongssi jinin suyong gwajeong: 'Jeonggamnok' tansaeng ui yeoksajeok baegyeong.” Joseon sidae sahakbo 60, p.137. (Korean)

Han, Seunghun, 2014, “Jeongeundae hangukng ui mesianijeum: joseon hugi jininchulhyeonseol ui hyeongtae deulgwa geu gongganjeok jeollyak." Jonggyo wa munhwa 27, p.43. (Korean)

Hong, Seongdeok, 2017, “Joseon hugi daeil insing ui sahoejeong tuyeong sarye: 'Chuangeupgugan' eul jungsim euro." Gangwonsahak 24:50-65. (Korean)

Hwang, Seonmyeong, 1999, “Sipseungjigo." Jonggyo wa munhwaa 5, p.169. (Korean)

Jang, Jihun, 1997, Hanguk godae mireuk sinang yeongu; (A Study of the Ancient Mytreya Faith in Korea). Seoul: Jimmundang, p.54. (Korean)

Ju, Ganghyeon, 1995, Maeul ro gan mireuk 2; (Maitreya Who Went to Town). Seoul: Daewonjeongsa. (Korean)

Ju, Ganghyeon, 2012, Yutopia ui tansaeng: seom-isanghyang/ieodo ui simseongsa; (The Birth of Utopia: Island-Utopia/History of the Mind of leodo). Paju: Dolbegae. (Korean)

Miyata, Noboru, 1968, “「Yonaoshi」 to miroku shinkō-Nihon ni okeru 「Yonaoshi」 no minzokuteki imi.” Minzokugaku kenkyū $33 / 1$, p.32. (Japanese)

Miyata, Noboru, 1971, “Okinawa no mirokugami.” Minzokugaku kenkyū 36/3: 254-255. (Japanese)

Miyata, Noboru, 1975, Miroku shinkō no kenkyū; (Study of Maitreya Faith). Tōkyō: Miraisha, pp. 211-270.

Sakihara, Kōshin, 1979, “Kayō ni miru miruku shinkō." Shimauta, pp.84-88. (Japanese)

Sudo, Yoshihito, 2003, "Ryukyu shoto ni okeru 'miroku' kan ni kansuru ichi kōsatsu: miroku kamen ga raihō shita kaijo no michi o saguru shiten." Okinawa daigaku chi'iki kenkyūjo nenpō 18:145-146. (Japanese)

Tabata, Hiroko, 2003, “Miroku shinkō: Okinawa to kankoku no miroku setsuwa no hikaku kenkyū." Okinawa bunks kenkyū 29:67-69. (Japanese) Yanagita, Kunio, 2005, Kaijō no michi (The Path of the Sea). Tōkyō: Iwanami Shoten, p.132. (Japanese) 